\title{
PEMBUATAN LAPISAN TIPIS SILIKON AMORF TERHIDROGENASI (a-Si:H) UNTUK BAHAN SEL SURYA
}

\author{
Wirjoadi, Sudjatmoko, Yunanto, Bambang Siswanto, Sri Sulamdari \\ Puslibang Teknologi Maju- Batan \\ Jl. Babarsari Kotak Pos 1008, Yogyakarta 55010
}

\begin{abstract}
ABSTRAK
PEMBUATAN LAPISAN TIPIS SILIKON AMORF TERHIDROGENASI (a-Si:H) UNTUK BAHAN SEL SURYA. Telah dilakukan pembuatan lapisan tipis silikon amorf terhidrogenasi (a-Si:H) untuk bahan sel surya. Lapisan tipis silikon amorf telah diketahui dan dapat dibuat, akan tetapi bahan lapisan tipis tersebut tidak dapat dimanfaatkan sebagai piranti elektronik. Pengontrolan valensi semi konduktor telah membuka jalan untuk pemanfaatan bahan tersebut untuk piranti-piranti elektro-nik terutama untuk piranti lapisan tipis photovoltaic, karena piranti photovoltaic seperti sel surya membutuhkan luasan aktif yang sangat besar untuk pengumpulan energi surya. Dalam penelitian ini deposisi lapisan tipis silikon amorf terhidrogenasi (a-Si:H) dilakukan dengan metode sputtering pada beberapa variasi parameter, yaitu suhu substrat, tekanan gas dan lama waktu deposisi untuk mendapatkan sifat listrik, terutama nilai resistivitas lapisan optimum. Berdasarkan perhitungan dan analisa data pengukuran dengan probe empat titik, maka lapisan tipis silikon amorf diperoleh hasil nilai resistansi sebesar $R=$ $(1,68 \pm 0,02) M \Omega$, nilai resistivitas $\rho=(1,80 \pm 0,05) \Omega m$ dan nilai konduktivitas $\sigma=(0,57 \pm 0,02)$ $\Omega^{1} m^{-1}$,yang ini diperoleh pada kondisi suhu $300^{\circ} \mathrm{C}$, tekanan gas $7 \times 10^{-2}$ torr, waktu deposisi $1,5 \mathrm{jam}$. Sedangkan hasil untuk lapisan tipis silikon amorf terhidrogenasi (a-Si:H) diperoleh nilai resistansi optimum sebesar $R=1349,66 \mathrm{M} \Omega$, pada suhu $300^{\circ} \mathrm{C}$, tekanan gas $3,8 \times 10^{-2}$ torr dan waktu deposisi 1,5 jam.
\end{abstract}

\begin{abstract}
FABRICATION OF HYDROGENATED AMORF SILICON (a-Si:H) THIN LAYER FOR SOLAR CELL MATERIAL. It has been fabricated of hydrogenated amorf silicon (a-Si:H) for solar cell materials. Amorf silicon thin layer has been known and has been fabricated, but this thin layer can not be used for electronics devices. The controlling of the semiconductor valences has opened way the application of the materials for electronics devices mainly for photovoltaic thin layer, because the electronics devices such as solar cell needs a large active area for collecting the solar energy. In this research, the deposition of hydrogenated amorf silicon ( $a-S i: H)$ thin layer has been done using sputtering technique for various of parameter such as substrat temperatur, gas pressure and the deposition time, this purpose is to get the optimum resistivity of the thin layer. Based or the calculation and data analysis measurement using four point probe it was found that resistance, resistivity and conductivity of the amot Silicon thin layer respectively was $R=(1,68 \pm 0,02) M \Omega$ and $\rho=(1,80 \pm 0,05) \Omega m$ and $\sigma=(0,57 \pm$ $0,02) \Omega^{1} m^{-1}$, this conditions was achieved at $300^{\circ} \mathrm{C}, p=7 \times 10^{-2}$ torr, $t=1,5$ hours. While for hydrogenated amorf silicon thin film (a-Si:H) the optimum resistance was $R=1349,66 \mathrm{M} \Omega$, this condition was achied at $T=300^{\circ} \mathrm{C}, p=3,8 \times 10^{-2}$ torr and $t=1,5$ hours.
\end{abstract}

\section{PENDAHULUAN}

$\mathrm{P}^{\mathrm{s}}$ ada saat ini sel surya silikon amorf telah menjadi perhatian bagi para peneliti karena biaya pembuatannya jauh lebih murah apabila dibandingkan dengan sel surya silikon kristal. Lapisan tipis silikon amorf telah diketahui dan dapat dibuat sebelum tahun 1969, akan tetapi bahan lapisan tersebut tidak dapat dimanfaatkan sebagai piranti elektronik. Dalam tahun 1970 R.C. Chittick dkk berhasil membuat silikon amorf (a-Si) dan Germanium amorf (a-Ge) dengan menggunakan metode lucutan pijar (glow discharge). Berdasarkan metode tersebut Spear dan Lecomber dari Inggris melaporkan bahwa elektron valensi tipe $\mathrm{p}$ 
dan tipe n dalam silikon amorf tersebut dapat dikontrol. Pengontrolan tipe $\mathrm{p}$ atau tipe $\mathrm{n}$ dilakukan dengan cara penambahan sejumlah kecil bahan dopan seperti fosfor atau boron ke dalam (a-Si:H).

Pengontrolan valensi semikonduktor telah membuka jalan untuk pemanfaatan bahan tersebut untuk piranti-piranti elektronik, terutama untuk piranti lapisan tipis photovoltaic, karena piranti photovoltaic seperti sel surya membutuhkan luasan aktif yang sangat besar untuk pengumpulan energi surya. Dalam hal ini bahan amorf mempunyai keuntungan yang sangat besar dalam pembuatan fabrikasi piranti-piranti yang mempunyai luasan besar dan seragam. Oleh karena itu apabila (a-Si:H) dapat dimanfaatkan sebagai piranti sel surya, maka biaya fabrikasi dapat ditekan serendah mungkin jika dibandingkan dengan sel surya berbahan silikon kristal.

Silikon amorf dapat dihasilkan beberapa metode antara lain metode lucutan pijar, evaporasi hampa atau metode sputtering. Dengan metode tersebut tidak hanya konduktivitas tipe $\mathrm{p}$ atau tipe $\mathrm{n}$ yang dapat dikontrol tetapi juga rapat pembawa muatannya. Tetapi pembuatan dengan metode tersebut akan menghasilkan banyak sekali tangan-tangan kosong (dangling bond) dalam jaringan silikon amorf. Tangan-tangan kosong tersebut menghasilkan keadaan celah terlokalisasi antar pita valensi dan pita konduksi. Keadaan terlokalisasi ini akan bertindak sebagai pusat rekombina-si pasangan elektron dan hole, kemudian pembawa muatan segera berkombinasi setelah pembentukannya oleh serapan foto sehingga dalam bahan tersebut tidak memperlihatkan sifat konduktivitas atau konduktansi listriknya sangat jelek. Untuk mengisi tangan-tangan kosong dilakukan hidrogenasi dengan menambahkan gas reaktif hidrogen pada proses sputtering. Dengan hidogenasi tersebut akan mengurangi secara drastis keadaan terlokalisasi pada celah pita terlarang. Sebagai akibatnya tingkat energi fermi akan tergeser oleh doping fosfor atau boron ke arah pita valensi atau pita konduksi sehingga valensi silikon amorf dapat dikontrol. Oleh karena itu dalam penelitian ini dilakukan pembuatan lapisan tipis silikon amorf terhidrogenasi (a-Si:H) untuk bahan sel surya dengan metode sputtering. ${ }^{(1,2)}$

Dalam penelitian ini tujuan utamanya adalah pembuatan lapisan tipis silikon amorf terhidrogenasi (a-Si:H) untuk bahan sel surya yang mempunyai sifat konduk-tivitas listrik optimum. Untuk mendapatkan lapisan tipis yang optimum telah dilaku-kan variasi parameter sputtering yaitu suhu substrat, tekanan gas, dan waktu deposisi. Dengan diperolehnya bahan-bahan tersebut, maka diharapkan akan dihasilkan sel surya silikon amorf (a-Si:H) lapisan tipis yang jauh lebih murah bila dibandingkan dengan sel surya silikon kristal. ${ }^{(3)}$

Dalam penelitian ini telah dilakukan deposisi lapisan tipis silikon pada substrat gelas dengan metode sputtering. Untuk mendapatkan lapisan tipis silikon yang optimum telah dilakukan variasi parameter sputtering yaitu suhu 250; 275, dan $300{ }^{\circ} \mathrm{C}$, tekanan gas $6 \times 10^{-2} ; 7 \times 10^{-2}$ dan $8 \times 10^{-2}$ torr, waktu deposisi 0,$5 ; 1 ; 1,5$ dan 2 jam. ${ }^{(4)}$ Berdasarkan perhitungan dan analisa data dari pengukuran dengan probe empat titik, maka diperoleh hasil nilai resistansi $\mathrm{R}=$ $(1,68 \pm 0,02) \mathrm{M} \Omega$, resistivitas $\rho=(1,80 \pm$ $0,05) \Omega \mathrm{m}$ dan konduktivitas $\sigma=(1,80 \pm$ $0,05) \Omega^{-1} m^{-1}$, ini diperoleh pada parameter suhu $300{ }^{\circ} \mathrm{C}$, tekanan gas $7 \times 10^{-2}$ torr dan waktu deposisi 1,5 jam. Sedangkan hasil untuk lapisan tipis silikon amorf terhidrogenasi (a-Si:H) diperoleh nilai resistansi optimum $\mathrm{R}=1.349,66 \mathrm{M} \Omega$, ini dicapai pada suhu $300{ }^{\circ} \mathrm{C}$, tekanan gas $3,8 \mathrm{x}$ $10^{-2}$ torr dan waktu deposisi 1,5 jam. Karakterisasi sifat-sifat optik lapisan tipis silikon untuk variasi suhu diperoleh hasil nilai transmitansi sekitar (84 - 82) \% pada suhu $250{ }^{\circ} \mathrm{C}$, (70-79) \% pada suhu $275{ }^{\circ} \mathrm{C}$ dan (10-30) \% pada suhu $300{ }^{\circ} \mathrm{C}$, ini pada posisi panjang gelombang $(600-1000) \mathrm{nm}$. 
Karakterisasi sifat-sifat optik lapisan untuk variasi waktu deposisi diperoleh hasil nilai transmitansi sekitar (56-73) \% pada waktu deposisi 0,5 jam, (43-76) \% pada waktu deposisi 1 jam, (30-61) \% pada waktu deposisi 1,5 jam dan (17-54) \% pada waktu deposisi 2 jam, perhitungan ini pada posisi panjang gelombang (600-1000) nm. Metode yang dipakai untuk karakterisasi sifat optik lapisan tipis adalah dengan peralatan spektrofotometer UV-vis.

Difraksi sinar-X adalah pola difraksi dari suatu benda uji dan salah satu teknik analisa untuk penentuan ukuran sel satuan kristal (struktur kristal). Dalam proses deposisi lapisan tipis, ada beberapa parameter penting dalam deposisi sputtering yang mempengaruhi mekanisme pertumbuhan kristal, struktur mikro atau morfologi permukaan (bentuk lapisan dan geometri struktur kristal atau amorf dalam lapisan) dan susunan atau pola difraksi. Dalam penelitian ini hasil pengukuran yang diperoleh dari difraksi sinar-X (XRD) yang berupa difraktogram menunjukkan bahwa lapisan tipis yang terdeposisi tersebut adalah amorf.

\section{TATA KERJA}

Dalam penelitian ini tahapan yang telah dilakukan meliputi persiapan bahan cuplikan untuk substrat, pembuatan target $\mathrm{Si}$, persiapan peralatan untuk penelitian, pelaksanaan penelitian, pendeposisian lapisan tipis silikon amorf pada substrat gelas, karakterisasi sifat-sifat optik (transmitansi) dan ketebalan hasil lapisan tipis silikon amorf dengan spektrofotometer UV-vis.

Persiapan Bahan

Bahan utama yang disiapkan dalam penelitian ini yaitu pembuatan bahan target serbuk silikon, kemudian dibuat dalam bentuk pelet. Sebelum akan dilakukan pembuatan pelet dengan pengepresan, serbuk Si dicampur sedikit Alkohol, kemudian diaduk-aduk dulu supaya kedua campuran bahan tersebut bisa merata atau homogen. Kemudian dibuat pelet untuk target $\mathrm{Si}$ berbentuk lempeng bundar berdiameter $60 \mathrm{~mm}$, tebal $2 \mathrm{~mm}$ dan dilakukan dengan tekanan pengepresan 200 N. Setelah terbentuk target Si yang sudah di pres selanjutnya dipanaskan pada suhu 1500 ${ }^{\circ} \mathrm{C}$. Sedangkan bahan pendukung penelitian lainnya yang telah disiapkan terdiri dari gas Argon, Hidrogen dan bahan gelas preparat yang digunakan sebagai substrat.

Persiapan Peralatan Penelitian

\section{a). Reaktor Plasma}

1. Tabung reaktor dari stainless steel yang dilengkapi dengan sebuah jendela kaca.

2. Pemegang target dan pemegang substrat.

3. Catu daya arus searah.

4. Alat ukur arus, tegangan dan vakum.

5. Pompa vakum (rotari dan difusi).

6. Pendingin target

7. Pemanas substrat

\section{b). Alat-alat karakterisasi}

1. Karakterisasi sifat-sifat optik (transmitansi) dengan peralatan UV-vis

2. Peralatan XRD (Difraksi Sinar X).

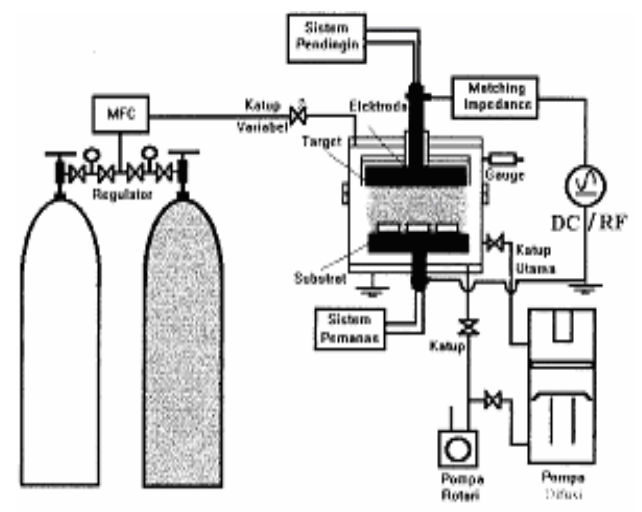

Gambar 1. Skema Sistem Deposisi Sputtering

\section{Pembuatan Substrat}

Substrat kaca dibuat dari bahan gelas preparat yang dipotong-potong dengan ukuran $1 \mathrm{~cm}$ x $2 \mathrm{~cm}$. Substrat tersebut dicuci dengan deterjen menggunakan ultrasonic cleaner. Kemudian dicuci lagi dengan 
alkohol juga dengan ultrasonic cleaner. Setelah bersih, substrat dibersihkan dengan tisue, dikeringkan dengan pemanas, kemudian dibersihkan lagi dengan aceton, selanjutnya dimasukkan dalam pembungkus plastik klip.

Pembuatan Lapisan Tipis Silikon Amorf

Pembuatan lapisan tipis silikon terhidrogenasi (a-Si:H) dilakukan dengan metode sputtering DC dan skema peralatan seperti yang ditampilkan pada Gambar 1. Target silikon dipasang pada katode dan substrat diletakkan pada anode. Udara di dalam tabung reaktor divakumkan dengan pompa rotari dan difusi yang tekanannya sampai dengan $10^{-5}$ torr dapat digunakan untuk membersihkan partikel-partikel yang tidak dikehendaki. Setelah beberapa menit pompa vakum difusi dimatikan, kemudian gas argon dan hidrogen dialirkan melalui kran, sehingga tekanan gas di dalam tabung reaktor akan naik menjadi $10^{-2}$ torr. Pada bagian katoda didinginkan dengan air pendingin supaya suhu pada target tidak naik karena tertumbuk ion argon. Kemudian pada bagian anoda (tempat substrat) justru dipanaskan untuk memperbesar frekuensi getaran atom substrat. Apabila penyedia daya tegangan tinggi DC dihidupkan, maka gas argon yang ada pada celah elektroda akan terionisasi. Ion argon akan menumbuki target Silikon dan ion argon akan bersenyawa dengan ion Silikon dan menumbuk substrat. Lapisan tipis yang terdeposisi pada substrat kaca tergantung pada suhu substrat, tekanan gas dan lama waktu sputtering. Pada proses deposisi lapisan tipis silikon ini, jarak anode dengan katode sekitar $2 \mathrm{~cm}$, beda tegangan anode-katode sekitar $2 \mathrm{kV}$, sedangkan parameter sputtering yaitu suhu substrat, tekanan gas, dan lama waktu deposisi sputtering, dilakukan sebagai berikut. ${ }^{(4,5)}$

Pendeposisian lapisan tipis dilakukan dengan menggunakan target Silikon. Suhu substrat $=(250-300){ }^{\circ} \mathrm{C}$, tekanan gas $=(6-$ 8) $\times 10^{-2}$ torr, waktu deposisi $=(0,5-2,0)$ jam, tegangan $=2 \mathrm{kV}$, arus $=15 \mathrm{~mA}$. dan tegangan DC tetap $=2 \mathrm{kV}$.

\section{Karakterisasi}

Untuk pengukuran karakterisasi sifatsifat optik (transmitansi) dan ketebalan lapisan tipis Silikon pada substrat gelas dilakukan dengan menggunakan peralatan Spektrofotometer UV-vis. Untuk pengamatan spektrum struktur kristal dilakukan dengan alat XRD, sedangkan untuk mengetahui struktur mikro lapisan tipis silikon dapat diamati dengan menggunakan peralatan Scanning Electron Microscopy (SEM).

\section{HASIL DAN PEMBAHASAN}

Dalam penelitian ini bahan cuplikan yang digunakan untuk deposisi lapisan tipis Silikon adalah gelas preparat. Untuk mendapatkan lapisan tipis silikon pada substrat gelas yang mempunyai sifat-sifat optik (transmitansi) optimum tergantung pada suhu substrat, tekanan gas dan lama waktu deposisi. Pembuatan lapisan tipis silikon pada permukaan substrat gelas telah dilakukan variasi suhu $\left(250{ }^{\circ} \mathrm{C}, 275{ }^{\circ} \mathrm{C}\right.$; 300 $\left.{ }^{\circ} \mathrm{C}\right)$, tekanan gas $\left(6 \times 10^{-2}\right.$ torr; $7 \times 10^{-2}$ torr; 8 x $10^{-2}$ torr), dan waktu deposisi ( 0,5 jam; 1 jam; 1,5 jam; 2 jam) dengan menggunakan metode sputtering dc. Hasil pengukuran karakterisasi sifat-sifat optik (transmitansi) dengan peralatan UV-vis, maka lapisan tipis silikon pada substrat gelas untuk variasi suhu ditunjukkan pada Gambar 2, sedangkan untuk variasi lama waktu deposisi ditunjukkan pada Gambar 3. 


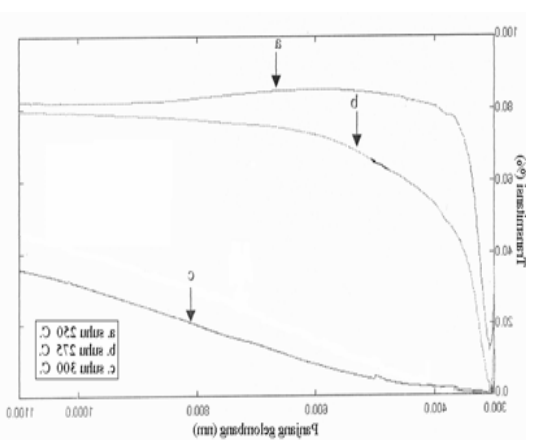

Gambar 2. Transmitansi lapisan tipis silikon untuk variasi suhu, pada tekanan gas 7 x $10^{-2}$ torr, waktu deposisi 1,5 jam dengan Spektrofotometer UV-vis

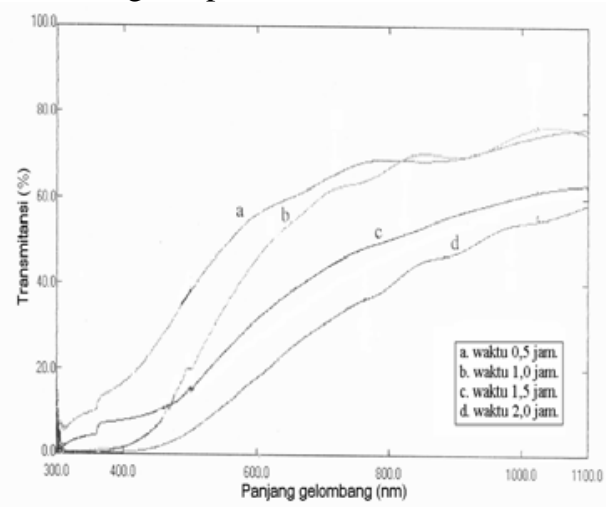

Gambar 3. Transmitansi lapisan tipis silikon untuk variasi waktu deposisi, pada tekanan $7 \times 10^{-2}$ torr, suhu $300{ }^{\circ} \mathrm{C}$ dengan Spektrofotometer UV-vis

Tabel 1. Data eksperimen deposisi lapisan tipis silikon untuk variasi suhu substrat.

\begin{tabular}{|c|c|c|c|c|}
\hline $\begin{array}{c}\text { Cuplika } \\
\mathrm{n}\end{array}$ & $\begin{array}{c}\text { Suhu } \\
\text { substrat } \\
\left({ }^{\circ} \mathrm{C}\right)\end{array}$ & $\begin{array}{c}\text { Tekanan } \\
\text { gas (torr) }\end{array}$ & $\begin{array}{c}\text { Waktu } \\
\text { (Jam) }\end{array}$ & $\begin{array}{c}\text { Daya } \\
(\mathrm{W})\end{array}$ \\
\hline $\mathrm{A}$ & 250 & $7 \times 10^{-2}$ & 1,5 & 30 \\
\hline $\mathrm{B}$ & 275 & $7 \times 10^{-2}$ & 1,5 & 30 \\
\hline $\mathrm{C}$ & 300 & $7 \times 10^{-2}$ & 1,5 & 30 \\
\hline
\end{tabular}

Tabel 2. Data eksperimen deposisi lapisan tipis silikon untuk variasi tekanan gas.

\begin{tabular}{|c|c|c|c|c|}
\hline $\begin{array}{c}\text { Cuplika } \\
\mathrm{n}\end{array}$ & $\begin{array}{c}\text { Tekanan } \\
\text { gas (torr) }\end{array}$ & $\begin{array}{c}\text { Suhu } \\
\text { substrat } \\
\left({ }^{\circ} \mathrm{C}\right)\end{array}$ & $\begin{array}{c}\text { Waktu } \\
\text { (Jam) }\end{array}$ & $\begin{array}{c}\text { Daya } \\
(\mathrm{W})\end{array}$ \\
\hline $\mathrm{D}$ & $6 \times 10^{-2}$ & 300 & 1,5 & 30 \\
\hline $\mathrm{E}$ & $7 \times 10^{-2}$ & 300 & 1,5 & 30 \\
\hline $\mathrm{F}$ & $8 \times 10^{-2}$ & 300 & 1,5 & 30 \\
\hline
\end{tabular}

Tabel 3. Data eksperimen deposisi lapisan tipis silikon untuk variasi waktu deposisi.

\begin{tabular}{|c|c|c|c|c|}
\hline $\begin{array}{c}\text { Cuplika } \\
\mathrm{n}\end{array}$ & $\begin{array}{c}\text { Waktu } \\
(\mathrm{Jam})\end{array}$ & $\begin{array}{c}\text { Suhu } \\
\text { substrat } \\
\left({ }^{\circ} \mathrm{C}\right)\end{array}$ & $\begin{array}{c}\text { Tekanan } \\
\text { gas (torr) }\end{array}$ & $\begin{array}{c}\text { Daya } \\
(\mathrm{W})\end{array}$ \\
\hline $\mathrm{G}$ & 0,5 & 300 & $7 \times 10^{-2}$ & 30 \\
\hline $\mathrm{H}$ & 1,0 & 300 & $7 \times 10^{-2}$ & 30 \\
\hline $\mathrm{I}$ & 1,5 & 300 & $7 \times 10^{-2}$ & 30 \\
\hline $\mathrm{J}$ & 2,0 & 300 & $7 \times 10^{-2}$ & 30 \\
\hline
\end{tabular}

Data hasil proses deposisi lapisan tipis silikon pada substrat gelas untuk variasi suhu ditunjukkan pada tabel 1 , untuk variasi tekanan gas ditunjukkan pada tabel 2, sedangkan untuk variasi waktu deposisi ditunjukkan pada tabel 3.

Berdasarkan perhitungan dan analisa data pengukuran dengan probe empat titik, maka cuplikan (A s/d J) lapisan tipis silikon amorf pada data tabel 1, 2, 3 yang terukur nilai resistansinya adalah hanya cuplikan C, sedangkan lainnya tidak terukur. Adapun cuplikan $C$ yang terukur diperoleh hasil nilai resistansi $\mathrm{R}=(1,68 \pm 0,02) \mathrm{M} \Omega$, resistivitas $\rho$ $=(1,80 \pm 0,05) \Omega \mathrm{m}$ dan konduktivitas $\sigma=$ $(1,80 \pm 0,05) \Omega^{-1} \mathrm{~m}^{-1}$, pada suhu $300{ }^{\circ} \mathrm{C}$, tekanan gas $7 \times 10^{-1}$ torr dan waktu deposisi 1,5 jam. Ketidak terukur-nya pengukuran nilai resistansi ini karena keterbatasan kemampuan alat ukur meter yang dimiliki dan kemungkinan ada faktor lain yang mempengaruhi yaitu proses pengepresan, pemanasan dalam pembuatan target dari serbuk silikon berbentuk pelet (bukan target silikon berbentuk wafer).

Hasil yang diperoleh nilai transmitansi lapisan tipis silikon amorf disajikan pada 
Gambar 2 untuk variasi suhu adalah sekitar (84 - 82) \% pada suhu $250{ }^{\circ} \mathrm{C}$, sekitar (70 79) \% pada suhu $275{ }^{\circ} \mathrm{C}$ dan sekitar (10 30) \% pada suhu $300{ }^{\circ} \mathrm{C}$. Ketiga lapisan tipis silikon ini perhitungan nilai transmitansinya dihitung pada posisi panjang gelombang (600-1000) nm. Nilai transmitansi lapisan tipis silikon untuk suhu $250{ }^{\circ} \mathrm{C}$ lebih besar bila dibandingkan dengan nilai transmitansi lapisan tipis silikon untuk suhu $275{ }^{\circ} \mathrm{C}$ dan $300{ }^{\circ} \mathrm{C}$. Hal ini disebabkan karena (apabila substrat gelas yang sebagian besar tersusun dari unsur silikon), suhunya semakin naik sehingga vibrasinya juga akan meningkat, maka atom-atom silikon target yang tersputter akan berdifusi sehingga atom-atomnya semakin masuk ke dalam susunan atom substrat. Dengan demikian semakin tinggi suhu substrat, maka lapisan tipis silikon yang dideposisi pada substrat gelas tersebut akan semakin tebal lapisannya sehingga menyebabkan nilai transmitansinya rendah.

Hasil yang diperoleh nilai transmitansi lapisan tipis silikon pada Gambar 3 untuk variasi waktu deposisi adalah sekitar (56 73) \% pada waktu deposisi 0,5 jam, sekitar (43 - 76) \% pada waktu deposisi 1 jam, sekitar (30 - 61) \% pada waktu deposi-si 1,5 jam dan sekitar (17 - 54) \% pada waktu deposisi 2 jam. Ke empat lapisan tipis silikon ini perhitungan nilai transmitansinya dihitung pada posisi panjang gelombang (600-1000) nm. Nilai transmitansi lapisan tipis silikon untuk waktu deposisi 0,5 jam lebih besar bila dibandingkan dengan nilai transmitansi lapisan tipis silikon untuk waktu deposisi 1 jam;1,5 jam dan 2 jam. Hal ini disebabkan karena dengan naiknya lama waktu deposisi, maka ketebalan lapisan tipis silikon yang terbentuk semakin meningkat sehingga nilai transmitansinya semakin turun.

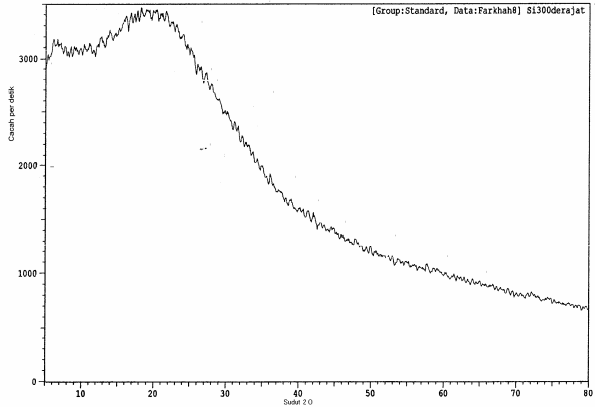

Gambar 4. Pola difraksi sinar-X lapisan tipis silikon amorf pada suhu $300{ }^{\circ} \mathrm{C}$, tekanan $7 \times 10^{-2}$ torr dan waktu deposisi 1,5 jam.

Tabel 4. Data eksperimen deposisi lapisan tipis silikon amorf terhidrogenisasi (a-Si:H) pada substrat gelas untuk variasi suhu substrat.

\begin{tabular}{|c|c|c|c|c|c|}
\hline Cuplikan & $\begin{array}{c}\text { Suhu } \\
\text { substrat } \\
\left({ }^{\circ} \mathrm{C}\right)\end{array}$ & $\begin{array}{c}\text { Tekanan } \\
\text { gas } \\
\text { (torr) }\end{array}$ & $\begin{array}{c}\text { Waktu } \\
\text { (jam) }\end{array}$ & $\begin{array}{c}\text { Daya } \\
\text { (watt) }\end{array}$ & $\begin{array}{c}\text { Resistansi } \\
(\mathrm{M} \Omega)\end{array}$ \\
\hline 1. & 250 & $\begin{array}{c}3,8 \mathrm{x} \\
10^{-1}\end{array}$ & 1,5 & 80 & $1.621,34$ \\
\hline 2. & 300 & $\begin{array}{c}3,8 \mathrm{x} \\
10^{-1}\end{array}$ & 1,5 & 80 & $1.349,66$ \\
\hline 3. & 325 & $\begin{array}{c}3,8 \mathrm{x} \\
10^{-1}\end{array}$ & 1,5 & 80 & $1.575,33$ \\
\hline 4. & 350 & $\begin{array}{c}3,8 \mathrm{x} \\
10^{-1}\end{array}$ & 1,5 & 80 & $1.685,00$ \\
\hline
\end{tabular}

Difraksi sinar-X adalah pola difraksi dari suatu benda uji dan salah satu teknik analisa untuk penentuan ukuran sel satuan kristal (struktur kristal). Kemudian dari pola difraksi, intensitas hamburan suatu atom dapat menentukan susunan atom dalam sel satuan (struktur kristal) dan dari posisi puncak-puncaknya dapat ditentukan bentuk dan ukuran sel satuan. Bentuk dan ukuran sel satuan dapat dinyatakan dalam panjang sumbu kristal a, b , c dan sudut diantara sumbu kristal $\alpha, \beta, \gamma$. Pola difraksi tersebut sangat berkaitan dengan struktur mikro atau ukuran butir dari target silikon yang terdeposit pada permukaan substrat. Dalam proses deposisi lapisan tipis, ada beberapa parameter deposisi sputtering yang mempengaruhi mekanisme pertumbuhan kristal, struktur mikro atau morfologi 
permukaan (bentuk lapisan dan geometri struktur kristal atau amorf dalam lapisan) dan susunan atau pola difraksi. Dalam penelitian ini hasil pengukuran yang diperoleh dari difraksi sinar-X yang berupa difraktogram menunjukkan bahwa lapisan tipis yang terdeposisi tersebut adalah amorf seperti ditampilkan pada Gambar 4.

Tabel 5. Data eksperimen deposisi lapisan tipis silikon amorf terhidrogenisasi (a-Si:H) pada substrat gelas untuk variasi tekanan gas.

\begin{tabular}{|c|c|c|c|c|c|}
\hline Cuplikan & $\begin{array}{c}\text { Suhu } \\
\text { substrat } \\
\left({ }^{\circ} \mathrm{C}\right)\end{array}$ & $\begin{array}{c}\text { Tekanan } \\
\text { gas } \\
\text { (torr) }\end{array}$ & $\begin{array}{c}\text { Waktu } \\
\text { (jam) }\end{array}$ & $\begin{array}{c}\text { Daya } \\
\text { (watt) }\end{array}$ & $\begin{array}{c}\text { Resistansi } \\
(\mathrm{M} \Omega)\end{array}$ \\
\hline 5. & 300 & $\begin{array}{c}3,8 \mathrm{x} \\
10^{-1}\end{array}$ & 1,5 & 80 & $1.349,66$ \\
\hline 6. & 300 & $\begin{array}{c}4,8 \mathrm{x} \\
10^{-1}\end{array}$ & 1,5 & 80 & $1.483,00$ \\
\hline 7. & 300 & $\begin{array}{c}5,8 \mathrm{x} \\
10^{-1}\end{array}$ & 1,5 & 80 & $1.830,00$ \\
\hline
\end{tabular}

Data hasil proses deposisi lapisan tipis silikon amorf terhidrogenasi (a-Si:H) pada substrat gelas untuk variasi suhu ditunjukkan pada tabel 4, untuk variasi tekanan gas ditunjukkan pada tabel 5

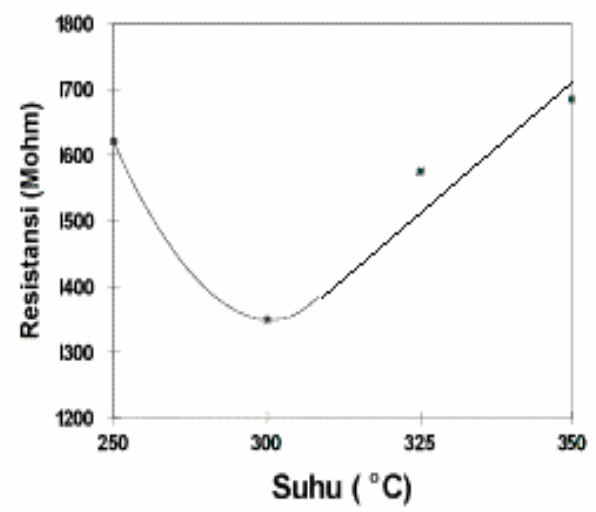

Gambar 5. Hubungan resistansi vs suhu pada tekanan $3,8 \times 10^{-1}$ torr, waktu deposisi 1,5 jam.

Hasil nilai resistansi yang diperoleh dalam proses deposisi lapisan tipis silikon amorf terhidrogenasi (a-Si:H) pada substrat gelas untuk variasi suhu ditampilkan pada Gambar 5 dan untuk variasi tekanan gas pada
Gambar 6. Pada saat kenaikan suhu dari (250 - 300) ${ }^{\circ} \mathrm{C}$, mobilitasnya juga semakin meningkat, maka atom-atom target yang tersputter akan berdifusi hingga atomnya masuk kedalam menyebabkan kerapatannya tinggi, sehingga nilai resistansi lapisannya mengalami penurunan. Pada suhu naik dari (300 - 350) ${ }^{\circ} \mathrm{C}$, maka kerapatan atom semakin renggang, sehingga nilai resistansi semakin tinggi dan nilai resistansi optimum pada suhu $300{ }^{0} \mathrm{C}$. Berdasarkan Gambar 6 ditunjukkan bahwa nilai resistansi lapisan tipis yang semakin meningkat apabila tekanan gas ditingkatkan, karena semakin besar tekanan gas akan semakin banyak atom-atom yang tersputter, sehingga akan meningkatkan ketebalan lapisan dan atom-atom yang masuk kedalam substrat semakin naik kerapatannya. Dengan demikian makin tinggi tekanan gas yang diberikan, maka nilai resistansinya juga semakin besar.

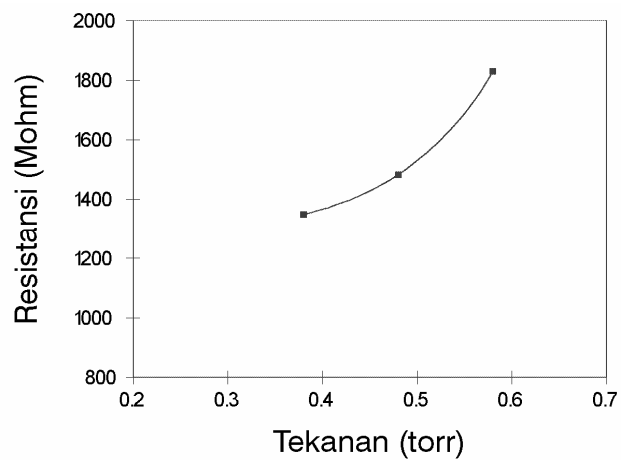

Gambar 6. Hubungan resistansi vs tekanan gas pada suhu $300{ }^{\circ} \mathrm{C}$, waktu deposisi 1,5 jam.

\section{KESIMPULAN}

Berdasarkan hasil penelitian yang dilakukan mengenai pembuatan lapisan tipis silikon amorf dengan metode sputtering dapat disimpulkan sebagai berikut.

1. Karakterisasi sifat-sifat listrik lapisan tipis silikon pada substrat gelas diperoleh hasil nilai resistansi $\mathrm{R}=(1,68$ $\pm 0,02) \mathrm{M} \Omega$, nilai resistivitas $\rho=(1,80 \pm$ 
$0,05) \Omega \mathrm{m}$ dan nilai konduktivitas $\sigma=$ $(0,57 \pm 0,02) \Omega^{-1} \mathrm{~m}^{-1}$.

2. Karakterisasi sifat-sifat optik (transmitansi) lapisan tipis silikon pada substrat gelas dengan spektrofotometer UV-vis untuk variasi suhu diperoleh hasil nilai transmi-tansi sekitar (84 - 82) \% pada suhu $250{ }^{\circ} \mathrm{C}$, sekitar $(70$ - 79) \% pada suhu $275^{\circ} \mathrm{C}$ dan sekitar (10 - 30) \% pada suhu $300{ }^{\circ} \mathrm{C}$, ketiga lapisan tipis tersebut pada posisi panjang gelombang (600 1000) nm.

3. Karakterisasi sifat-sifat optik (transmitansi) lapisan tipis silikon pada substrat gelas dengan spektrofotometer UV-vis untuk variasi waktu deposisi diperoleh hasil nilai transmitansi sekitar (56 - 73) \% pada waktu deposisi 0,5 jam, sekitar (43 - 76) \% pada waktu deposisi 1 jam, sekitar (30 - 61) \% pada waktu deposi-si 1,5 jam dan sekitar (17 - 54) \% pada waktu deposisi 2 jam, keempat lapisan tipis tersebut pada posisi panjang gelombang (600 - 1000) nm.

4. Karakterisasi struktur kristal lapisan tipis silikon pada substrat gelas, berdasarkan hasil pengukuran dengan difraksi sinar-X yang berupa difraktogram menunjukkan bahwa lapisan tipis yang terdeposisi tersebut adalah amorf

5. Karakterisasi sifat-sifat listrik (resistansi) lapisan tipis silikon amorf terhidrogenasi (a-Si:H) untuk variasi suhu substrat pada tekanan gas 3,8 x $10^{-1}$ torr, lama waktu deposisi 1,5 jam dan optimum pada suhu $300{ }^{\circ} \mathrm{C}$.

6. Karakterisasi sifat-sifat listrik (resistansi) lapisan tipis silikon amorf terhidrogenasi (a-Si:H) untuk variasi tekanan gas pada suhu $300{ }^{\circ} \mathrm{C}$, waktu deposisi 1,5 jam dan optimum pada posisi tekanan gas $3,8 \times 10^{-1}$ torr.

\section{UCAPAN TERIMA KASIH}

\begin{tabular}{lrr}
\multicolumn{1}{c}{ Pada kesempatan ini } & penulis \\
mengucapkan terima kasih & yang \\
setulus-tulusnya kepada saudara Drs. Tjipto
\end{tabular}

Suyitno, MT atas sumbang saran dan diskusi ilmiahnya tentang penelitian ini.

\section{DAFTAR PUSTAKA}

1. KATSUYA TABUCHI, WILSON W. WENAS, MASAHIRO YOSHINO, A. YAMADA, "Optimation of ZnO Film for Amorphous Silicon Solar Cells”, 11 th European Photovoltaic Solar Energy Conference and Exhibition, Montreux, Switzerland, 12-16 October 1992.

2. KATSUYA TABUCHI, WILSON W. WENAS, AKIRA YAMADA, "Optimization of $\mathrm{ZnO}$ Film for Amorphous Silicon Solar Cells", Jpn, J. Appl. Phys, Vol, 32 (1993), Part I, No. 9A, 3764-3769.

3. K. TAKAHASHI AND M. KONAGAI, "Amorphous Silicon Solar Cells", Nort Oxford Academic Publishers Ltd, (1986).

4. MAKOTO KONAGAI, "Device Physics and Optimum Desaign of (a-Si) Solar Cell", 5 th "Sunshine" Workshop on Solar Cells, December 8-9, (1992), Tokyo, Japan.

5. TADATSUGU MINAMI, HIDEO SONOHARA, SHINZO TAKATA AND ICHIRO FUKUDA, "Low Temperature Formation of Textured ZnO Transparent Electrodes by Magnetron Sputtering", J. Vac. Sci. Technol. A 13 (3), May/Jun (1995). 